\title{
Adverse Event Caused Study Discontinuation
}

National Cancer Institute

\section{Source}

National Cancer Institute. Adverse Event Caused Study Discontinuation. NCI Thesaurus.

Code C82496.

An indication or description of whether the adverse event caused the subject to

discontinue from the study. 